NOTAS

$149-164$

\title{
LOS ARCHIVOS DE LA NIEBLA (EN TORNO A REDUCCIONES DE JAIME HUENÚN VILLA) ${ }^{1}$
}

\author{
Sergio Mansilla Torres*
}

\section{A MODO DE ACLARACIÓN PRELIMINAR}

En octubre de 2011, Jaime Huenún tuvo la gentileza de entregarme la versión íntegra de Reducciones, libro mayor (183 páginas en la edición príncipe) en el que el poeta trabajó sistemáticamente durante más de una década, con la expresa petición - que me honra por cierto- de que escribiera una breve reflexión que sirviera de ayuda al lector a la hora de aventurarse por los complejos senderos poéticos del libro; la nota se incluiría, a modo de apéndice, en una versión impresa de Reducciones, entonces programada su edición entre diciembre de 2011 y enero de 2012. El libro se publica finalmente en abril de 2012, en Santiago de Chile, por la Editorial LOM, y lo que iba a ser en principio un apéndice se convirtió en el prólogo del volumen (pp. 11-20). En octubre de 2013 Reducciones fue galardonado con el Premio a las Mejores Obras Literarias, otorgado por el Consejo del Libro y la Lectura, luego de que el jurado lo considerara unánimemente el mejor libro de poesía publicado en Chile en $2012^{2}$. Una versión ampliada de esa nota —el prólogo — se leyó en el coloquio "Colonialidad/ Decolonialidad del Poder/Saber. Miradas desde el Sur", realizado en la Universidad Austral de Chile, Valdivia, el 10 y 11 de noviembre de 2011. El presente trabajo es una versión revisada y nuevamente ampliada del texto de la conferencia. He querido, por lo mismo, mantener un cierto tono de oralidad, en consonancia, además, con la oralidad que subyace en el tono general de Reducciones y que convive con una muy aguda conciencia escritural de parte de Huenún.

El presente trabajo está concebido no precisamente como un análisis técnico del libro - cuya complejidad, dicho sea de paso, reclama un estudio exhaustivo que desbordaría de lejos la dimensión de un artículo-, sino más bien como una incitación a comprender las condiciones históricas, culturales, territoriales que hicieron posible (y necesaria) la emergencia de un libro como Reducciones, el que, entre otras cosas, llama a la tarea de pensar el sujeto indígena (que es también mestizo) no solo en la posición de víctima eterna de un colonialismo que, pareciera al menos, muta todo el tiempo justamente para no cambiar. Huenún, muy consciente de que el solo alegato contra la dominación colonialista, la sola indignación dolida que suscitan las

\footnotetext{
${ }^{1}$ Trabajo que forma parte de la ejecución del Proyecto Fondecyt 1110026, financiado por el Fondo Nacional de Ciencia y Tecnología de Chile.

2 Es uno de los premios literarios más importantes que se otorga anualmente en Chile, en los géneros de poesía, narrativa, drama y ensayo, en categorías inéditos, expresamente enviados al concurso, y publicados. En este último caso se consideran solo libros publicados el año anterior. En 2013 fue la vigésima ocasión en que se otorgó este Premio.
} 
injusticias, la defensa irrestricta de una etnicidad "esencial" y en última instancia excluyente, no bastan para conformar una escritura poética que, siendo política y culturalmente comprometida, sea, por sobre todo, una compleja trama de voces provenientes de mundos literarios y no literarios, de imaginación y memoria, cuyas sutilezas semánticas den paso a una densidad estética de alto impacto.

Entiéndase este trabajo también como la expresión de la búsqueda de un modo de leer una cierta literatura en la que las localías territoriales y la gente que las habita constituyen referentes ineludibles de la escritura, de manera tal que la "ficción literaria" queda en cierto modo cancelada a la par que potenciada la función performativa de esta a la hora de reconfigurar la memoria histórica desde la perspectiva de un sujeto que ha heredado despojos y que asume su identidad cultural como un proceso en curso, abierto, que se despliega, que se va haciendo, en la poesía. Deliberadamente he omitido la discusión teórica acerca de conceptos claves y he optado por un uso "blando" de nociones como mestizaje, heterogeneidad cultural y otras; en parte porque ya existe una potente tradición crítica al respecto en el pensamiento latinoamericano contemporáneo a la que el lector puede acceder fácilmente; en parte porque Reducciones exige una lectura líquida en la que las categorías analíticas operen más bien como sugerentes insinuaciones que invitan a una permanente transitividad y difuminación de límites entre la historia y la poesía.

\section{LOS LUGARES DE LA MEMORIA}

Para empezar, oigamos el testimonio de María Matilde Huenún Huenún, abuela paterna del poeta Jaime Huenún, evocando episodios de despojos y mutilaciones de su mundo infantil:

Tendría yo unos 7 años cuando mi mamita me llevó a la misión de Quilacahuín. Nosotros éramos de Río Bueno, del campo. Alli tenía mi mama una ranchita. Ella hacía de todo, tejía en su telar, hacía quesitos, tejía mantas y choapinos, me acuerdo. De todas partes venían a comprarle mantas, le mandaban a hacer frazadas. Después todo eso se terminó. El pedacito de tierra donde vivíamos era una sucesión. Parece que llegaron parientes a reclamar ese pedazo de tierra y se perdió todo. Y qué le iba a hacer mi mamita, ella era sola, se tuvo que ir a trabajar al pueblo y a mí me dejó interna en la misión, ella no me podía ir a ver. Alli en la misión nos enseñaban a leer, las mujeres aparte y los hombres aparte. También nos enseñaban a coser, a tejer, a cocinar. Había una monjita viejita que era muy buena. Cuando me veía llorando me decía: 'no llores, hijita, ayúdame mejor aqui'. Y yo le ayudaba a hacer pan o a coser. Después, como al año sería, mi mamita se puso de acuerdo con una gringa de Trumao y me puso a trabajar. Yo era niña de mano y tenía que ayudar a las otras empleadas.

(María Matilde Huenún Huenún, 88 años) (95-96) ${ }^{3}$

\footnotetext{
${ }^{3}$ Testimonio recogido en Reducciones. Forma parte del texto "Entrada a Chauracahuín" que, a su vez, da nombre a una sección completa de Reducciones. Este mismo texto, de manera independiente, se publicó en 1999 en el libro Metáforas de Chile, ed. Pedro Araya. Al momento de terminar el manuscrito para 150
} 
Quien hoy, 80 años después del episodio evocado por María Matilde Huenún, suba hasta lo alto de la colina en la que se emplazan las instalaciones de la Misión de Quilacahuín, en la provincia de Osorno, sur de Chile, y dirija su mirada en dirección suroeste, verá el imponente río Rahue allá abajo hasta donde se pierde la mirada. En días tranquilos, cual lenta serpiente de azogue, el río se desplaza hacia el Pacífico partiendo en dos mitades las fértiles vegas del valle de Quilacahuín. Pero el Rahue no siempre es manso. Las copiosas lluvias invernales del sur chileno lo vuelven un animal feroz, turbio, enrabiado, tanto que a menudo no cabe en su cauce e inunda entonces los terrenos aledaños reiterando un viejo gesto natural que, a primera vista, parece catastrófico, pero que no es sino el trabajo entrelazado - una "ceremonia de amor"- de la tierra acogedora unida a las "aguas potras" (Huenun dixit). Los vivientes de esos lugares, conocedores de los cambios de humor de las estaciones, construyen casas de madera - muy modestas en la mayoría - cuyo primer piso es una especie de bodega o corral inundable, al tiempo que la vida familiar acontece en lo que sería el segundo piso al que se accede por escaleras exteriores.

Quilacahuín, cuya fama por los territorios de Osorno se debe a que produce legumbres singularmente tiernas y sabrosas (las lentejas de Quilacahuín son una delicia completa), es una tierra bella, pero de contrastes brutales: la imponente misión de Quilacahuín, con su templo católico, su colegio, su hospital primario, sus dependencias para visitantes y turistas, construidas en lo alto de una colina desde la que se domina el amplio valle así como una no menor extensión de la cordillera de la costa osornina, recuerda demasiado de cerca el viejo castillo feudal europeo, vigilante, omnipresente; esa especie de lugar temible allá arriba en el que moraba el Señor quien, desde una suerte de panóptico poderoso, controlaba y vigilaba a los siervos de allá abajo. Expresión material de la epistemología blanca colonial que hace suya la construcción de un saber autodefinido como civilizador, el que, providencialmente, arrancará a los indios de las tinieblas de la ignorancia y del pecado curando males del cuerpo y del alma. No es, pues, casual que la Misión de Quilacahuín contenga iglesia, colegio con internado y hospital, además de cementerio.

“¡Dios, que buen vassalo! ¡Si oviesse buen señor!”, leemos en el verso 20 del Poema de Mio Cid. El juglar medieval lo recitaría emocionado tal vez, animado en todo caso - se me figura - por la convicción de que instituir un orden de cosas terrenal que fuera adecuadamente salvífico pasaba por esa especie de ensamble entre el buen señor y el buen vasallo, porque esto aseguraría protección mutua, el cultivo de valores nobles y heroicos, y, quizás lo más importante, porque otorga sentido providencial a las vidas que tendrían entonces que transcurrir como soberbias actuaciones en el gran teatro del mundo, según el lugar que a cada uno le haya tocado en la escala del vivir. Acaso queriendo prolongar o revivir esta utopía medieval, las

Metáforas..., María Matilde, quien lamentablemente falleció en el segundo semestre de 2013, contaba con 76 años, dato registrado en Metáforas... Asimismo, al momento en que Huenún cierra el manuscrito de Reducciones, Matilde contaba con 88 años, dato consignado en el libro. Las itálicas son del autor. 
misiones católicas instaladas en territorios indígenas apostaron a construir un entorno de evangelización que asegurara la salvación de las almas de tantos naturales que no habían tenido — se decía - la oportunidad de conocer al "dios verdadero" y, de paso, salvar también no pocas almas de pecadores blancos haciendo descansar en ellos la responsabilidad de asumir la misión de allegar más feligreses a la Iglesia Católica que tiene, como lo indica su nombre, pretensiones de ser universal. A menudo ese entorno de evangelización semejaba un oasis, material o espiritual, de pacífica colonización, fundado seguramente en la creencia de que el "salvaje" de las tierras americanas podría civilizarse pasando por fuera de la violencia esclavizadora y homicida ${ }^{4}$.

Jaime Luis Huenún Villa, poeta autor de Reducciones, proviene de la clase de los que miran el castillo desde abajo. Pertenece a aquellas gentes que viven de lo poco que (les) va quedando después de largos y crueles despojos de tierra, de memoria y lengua; despojos que vienen desde el siglo XVI, pero que, como Huenún lo consigna en su libro, para el caso mapuche-huilliche adquirieron características de genocidio cultural a partir de mediados del siglo XIX cuando el Estado chileno emprende la ocupación definitiva de los territorios indígenas del sur del país (mapuche y mapuchehuilliche). ${ }^{5}$ Migraciones forzadas del campo a la ciudad (a los baldíos de la ciudad, habría que decir); asesinatos y aun masacres (v. g., la de Forrahue en 1912 documentada en Reducciones); niñas y niños tempranamente obligados a trabajar como sirvientes en las casas y haciendas de las elites económicas de la república, o arrancados del seno familiar e internados en escuelas católicas donde los disciplinaban para la desmemoria. Dioses y abuelos quedan entonces reducidos a hilachas. Y abundarán los exilios en la tierra que era propia, pero que de pronto fue ocupada por extraños; la ruka reducida a rancha, a barracón municipal o a callampa urbana en barrios que no son barrios: de esto habla el libro Reducciones ${ }^{6}$. Y habla de esto porque el libro es, centralmente, un

\footnotetext{
${ }^{4}$ La cruz y la espada son los viejos símbolos de la conquista y colonia de las tierras que hoy conforman América Latina. Las misiones evangelizadoras apostaban, por cierto, a la cruz, lo que más de una vez generó tensiones entre la Iglesia y la Corona española en el periodo colonial (e. g. expulsión de los jesuitas en 1767). Ya en el periodo republicano, la Iglesia generalmente actuó como una especie de mitigadora de los dramáticos efectos de las colonizaciones y despojos de territorios indígenas durante la expansión y consolidación de los estados nacionales en el siglo XIX e inicios del XX, aunque a la postre tal mitigación terminara igualmente siendo otro modo de colonizar la mente y de acabar con la cultura originaria.

${ }^{5}$ El lector hallará una muy bien documentada información histórica acerca de la expansión de Chile en el siglo XIX a costa de territorios indígenas sureños que de hecho o de derecho eran autónomos o no integrados a la república en Historia del pueblo mapuche, de José Bengoa.

${ }^{6}$ Ruka (o ruca): casa indígena mapuche tradicional, circular, hecha de fibra vegetal. En las riberas del río Damas, afluente del Rahue y que bordea la parte noreste de la ciudad de Osorno, existieron por años los "barracones municipales"; eran largos galpones dispuestos de modo paralelo, divididos longitudinal y transversalmente y con 10 habitaciones por lado que hacían las veces de "departamentos", separados los galpones por callejuelas estrechas sin pavimentar. Con grifos comunes, sin más instalaciones sanitarias que pozos negros de uso compartido, eran paupérrimos en materia de servicios básicos. Se construyeron en 1950 y los últimos fueron erradicados recién en la década de 1980. La mayoría de sus habitantes, de origen indígena-mestizo, provenían de áreas rurales, campesinos sin tierras, inquilinos expulsados de los fundos agrícolas. Huenún mismo se cría en la población "Nueva Esperanza" (sector 152
} 
documento de barbarie escrito con los materiales que conforman la obliterada historia del sistemático exterminio de la cultura indígena en los territorios Sur Patagonia del continente; alegato sostenido contra la vergüenza colonial y republicana que las agencias oficiales del Estado chileno encargadas de perfilar la memoria nacional velan lo suficiente como para que los indígenas de antaño no pasen de ser héroes ficcionalizados de una historia más o menos remota. Y para que los indígenas de hoy - como por desgracia ocurre todavía - no sean vistos más que como agitadores resentidos, en potencia o en acto, a los que hay que reprimir, dividir o bien comprar con prebendas, dinero o promesas de algún deslumbrante desarrollo cuya plusvalía no va a parar precisamente a las comunidades originarias.

No es de extrañar entonces que las piadosas monjas de la Misión de Quilacahuín se hicieran cargo de la educación y manutención de niños indígenas separados de sus familias por la fuerza de la violencia o como consecuencia de la desesperante miseria. Así el camino hacia la borradura total del origen quedaba expedito: hablar solo en español, rezar solo al dios cristiano y a sus vírgenes y santos, aprender oficios de baja complejidad para servir con eficiencia a patrones blancos. Para una niña sola, obligada a trabajar a sus 8 años como "niña de mano", aprender a ser una buena subalterna en un escenario de extrema desigualdad social es algo que garantizaría algún grado de incorporación (precaria, pero incorporación al fin) a la sociedad global occidental. ${ }^{7}$ No tengo por qué dudar de la bondad de la "monjita viejita" a la que se refiere Matilde Huenún y que morigeraba, como mejor podía y sabía, la inmensa soledad y tristeza de una niña de 7 años consciente de que su madre, por la separación, sufría tanto o más que ella misma. Monja que con su gesto maternal y misericordioso, a su pesar tal vez, era parte de un engranaje de poder institucionalizado diseñado para que la modernidad capitalista se expanda y se apropie de territorios cuyos habitantes aborígenes estaban, por entonces, lejos de organizar sus vidas en una sociedad compatible con la acumulación originaria, indispensable para que el "progreso" se materializara en los términos soñados por una elite política y económica que idolatraba la modernidad parisina y la industriosa inteligencia práctica de los alemanes. No por nada fueron emigrantes alemanes, y algunos franceses, quienes, por iniciativa del gobierno de la época, colonizaron las tierras de la Futahuillimapu (Grandes Tierras del Sur) a partir de 1851, las mismas en las que nacería Huenún un siglo después, descendiente de indios mestizados y empobrecidos.

Francke de Osorno, noroeste), originalmente un campamento resultado de una toma de terreno a inicios de la década de 1970 por gente sin casa y sin tierra. Agradezco al constructor de casas José Huisca Molina, el maestro Pepe, haberme informado acerca de los barracones municipales de Osorno en los que él mismo vivió de niño.

${ }^{7}$ La sociedad occidental, la nuestra, tiende excluyentemente a la autorreferencia, y a menudo no tolera al otro sino como pieza que obligadamente ha de insertarse en el statu quo y siempre que no provoque un cortocircuito en la hegemonía de las elites económicas, políticas y culturales. Más allá del hecho de que pueden citarse innumerables excepciones, en términos históricos el colonialismo moderno a escala global ha sido y es propio de la sociedad europeo-occidental. 
Sin embargo, y contra la laminación forzada de la cultura aborigen, la memoria radical mapuche y mapuche-huilliche, cual porfiada corriente en el subsuelo de la nación chilena, ha sobrevivido contra viento y marea. Y aún más: en los últimos años se ha fortalecido dando paso a un proceso de reetnización cuyos alcances están todavía por verse. Como fuere, el reclamo por reconocimiento cultural viene, de un tiempo a esta parte, brotando incontenible por las fisuras de una sociedad olvidadiza pero que poco a poco, por emergencia incontrarrestable de nuevas realidades socioculturales, ha ido aceptando su naturaleza pluricultural e historizando más y mejor su pasado, proceso en el que la poesía de las memorias culturales, como la que hallamos en Reducciones, ha venido cumpliendo, dicho sea, un rol nada despreciable.

\section{CONTRA LAS REDUCCIONES DE LA HISTORIA}

Si Reducciones se redujera a un recuento de tropelías y estropicios cometidos contra los mapuches y mapuches huilliches a lo largo de cinco siglos, sí que sería una poesía reducida: reducida a lamento, a victimización invasiva y paralizante de la subjetividad. Y la consecuencia sería un peligroso adelgazamiento del espesor semiótico de una historia de colonialismo que ha devenido daño identitario iqué duda cabe! para los pueblos indígenas; daño que, por otra parte, no cesa de denunciarse a lo largo de la centena y media de páginas que componen el volumen. Pero tal como Henún certeramente lo tematiza en su libro, esta misma historia ha dado paso a la emergencia de nuevas identidades que toman la forma de mestizajes múltiples, dinámicos, subversivos, dolorosos a veces. Nuevas identidades surgidas, en última instancia, de la necesidad de sobrevivir y que se tornan, por lo mismo, estratégicamente funcionales a la diversidad cultural-política que entra en juego a la hora de negociar con (y ser parte de) la modernidad nacional-global. Reducciones es, en este sentido, una propuesta poética de superación de las reducciones históricas de las que el pueblo mapuche ha sido víctima mediante la expropiación, para fines de escritura poética, de voces subalternas y dominantes que son puestas a parlamentar en un espacio textual en el que se evidencian las reducciones de los sujetos parlantes a su sola posición de poder (o a la de su carencia) al ser hablados por la unilateralidad de sus propios discursos.

Huenún, atento al romanceo de muertos y vivos, registra la porfiada persistencia de voces que parecían apagadas hace tiempo, pero que, en rigor, subsisten en cada hueso mondo en los cementerios del tiempo y los lugares - tanto en cementerios que tienen tumbas como en aquellos hechos solo de tierra y aire-, voces que están ahí murmurando sus destinos en las raíces invisibles de los canelos talados y en los pocos que aún quedan en las cordilleras de Chile; sujetos de vidas jibarizadas que hablan por medio de las letras tristes de las rancheras mexicanas cantadas a tono de alcohol pendenciero y lluvia; en fin, cuerpos parlantes que se hacen notar en viejos archivos de bibliotecas y museos que describen a los indios como raras excrecencias del género humano (a veces ni siquiera alcanzan a entrar en el rango de los humanos); descripciones que remachan el excluyente etnocentrismo del "civilizado" y que, por lo 
mismo, documentan la barbarie blanca que se manifiesta en un sofisticado y perverso uso de la razón cognoscente para fines de dominación, uso que se disfraza no obstante de ciencia objetiva. Algo que viene, de por sí, a refrendar una no menor incapacidad de base de la así llamada cultura "occidental-cristiana" para empatizar con la otredad radical.

Los Blancos, lo que caracteriza

a los eternos Blancos

es que ahora viven examinándonos,

a nosotros, los muy viejos,

a nosotros, los ya muertos.

(Canción aché-guayakí) (69)

Francisco Pascasio Moreno, el Perito Moreno, en 1875 escribía este testimonio que retrata de cuerpo entero a los "eternos blancos":

Creo que no pasará mucho tiempo sin que consiga los huesos de toda la familia de Catriel. Ya tengo el cráneo del célebre Cipriano, y el esqueleto de su mujer, Margarita; $\mathrm{y}$ ahora parece que el hermano menor Marcelino no vivirá mucho tiempo, pues ha sido el jefe de la actual sublevación y se ha rendido anteayer en el arroyo Nievas ante los Remingtons de Levalle. La cabeza de Catriel sigue aquí conmigo; hace rato que la revisé, pero aunque la he limpiado un poco, sigue siempre con bastante mal olor. Me acompaña al Tandil porque no quiero separarme de esta joya, la que me es bastante envidiada (71).

Reducciones, como se adelantó, es una polifonía que conforma un vasto y persistente relato de resistencia. Mas también es un relato de capitulaciones, de derrotas, de nomadías a la tierra hollada en la que crecen palabras igualmente holladas, llenas de remiendos. El libro se nos propone, pues, como un repertorio de voces y sujetos, subalternos los más, que hablan un español salpicado con los retazos de un idioma originario ya perdido. Y cuando habla el sujeto colonizador, lo hace en un español arcaico que nos retrotrae a la Conquista, pero que también es, para el indígena, huella presente de su propia identidad derrotada, reducida y contestada en la escritura poética. Un hablar entonces en una especie de lengua entre -lengua escorada, la llamará Rodrigo Rojas; lengua champurria, la llamará el propio Huenún ${ }^{9}$ - que se arma con pedazos, no siempre ensamblables, de la lengua de Castilla, antigua y de ahora, y la lengua de la Futahuillimapu. Y con esa champurria, Huenún arma una poesía que convoca fragmentos de la tierra de arriba y de abajo (la Wenu Mapu y la Minche Mapu, espacios metafísico-religiosos contrarios y a la vez

\footnotetext{
${ }^{8}$ Aché-Guayakí: etnia paraguaya, nómades recolectores hasta la década de 1970, reducida hoy a poco más de un millar de individuos. El texto transcrito de la canción guayakí así como el de Moreno que viene a continuación forman parte de Reducciones, sección "Cuatro cantos funerarios". Itálicas del autor.

${ }^{9}$ Rodrigo Rojas. La lengua escorada... La noción de "champurria" Huenún la viene sosteniendo desde hace varios años; alude a un modo de hablar un castellano alterado por el efecto de una lengua de sustrato, el mapudungun o su variante el che sungun, o de los residuos arcaicos de la propia lengua castellana hablada por los conquistadores.
} 
interdependientes), experiencias varias que arrancan de la mirada a lo cotidiano tanto como de la visión reveladora que hace entrever las continuidades entre lo natural histórico y lo sobrenatural cósmico. La champurria poética de Huenún es, pues, una lengua trabada por los cruces y las asimetrías culturales.

Así se va configurando una textualidad que registra pulsiones que se encaminan tanto a lo que podríamos llamar la desetnización como a la reetnización de los sujetos, movimientos que a la vez se oponen y se complementan de maneras asimétricas en tanto responden a cambiantes estrategias de sobrevivencia subalterna que implica capitulaciones e insubordinaciones identitarias según momento y lugar. El resultado es, por cierto, una heterogeneidad cultural (y psíquica) siempre en proceso, plástica, receptiva a la mutabilidad constante de las relaciones inter e intraculturales en un contexto de desigualdad contestada. No es casual que la cultura mapuche-huilliche, como sabemos muy mestizada a estas alturas de la historia, haya producido y esté produciendo poetas modernos, como Huenún mismo ${ }^{10}$, que pueden, según necesidades de representación discursiva, entrar y salir (digámoslo así) de las estéticas que circulan en localías "premodernas", populares, periféricas, bárbaras (Sarmiento dixit), así como de la sofisticada modernidad estética "vanguardista", modernidad esta —urbana, metropolitana, primermundista - en la que el componente étnico y territorial periférico no instituye (o lo hace muy excepcionalmente) poéticas de la memoria recuperativa.

Reducciones se inaugura con la sección "Entrada a Chauracahuín", topónimo indígena que designa lo que hoy es la ciudad de Osorno y sus alrededores y que es también el lugar de infancia del poeta. Recuperar el topónimo originario es parte de una vasta operación de "redescubrimiento de América" desde los ojos de quienes, al ocurrir el histórico "descubrimiento de América", fueron víctimas de la borradura colonial de su ser. Entrar a Chauracahuín es, pues, develar la opacidad de Osorno de manera que se hagan visibles las huellas de una historia trágica que son constitutivas de un presente que no ha de reducirse a la estereotipada y autocomplaciente imagen de un progreso providencial y aséptico ${ }^{11}$. No hay nostalgia de un Chauracahuín presuntamente paradisíaco. El Chauracahuín que la poesía de Huenún puede rememorar es una mezcla mestizada de memoria trágica, imaginación transformadora y deseo de sutura de las heridas históricas que en su momento provocó, y aún provoca, la violencia colonial; heridas que si no se las visibiliza y reconoce como constitutivas de la sociedad chilena,

${ }^{10}$ De la territorialidad sur huilliche (actuales provincias de Valdivia, Osorno y Llanquihue), en años recientes han surgido, por filiación o afiliación, poetas de origen indígena que reivindican la etnicidad, como Graciela Huinao, Faumelisa Manquepillán, César Millahueique, Paulo Huirimilla, Bernardo Colipán, Adriana Paredes Pinda, Roxana Miranda Rupailaf, entre otros.

${ }^{11}$ Recordemos que Osorno ha tenido tres fundaciones. La primera en 1553 por Pedro de Valdivia; se llamó entonces Santa Marina de Gaete. La segunda en 1558 por el gobernador García Hurtado de Mendoza; se llamó San Mateo de Osorno. En esa oportunidad acompañó al gobernador el poeta Alonso de Ercilla y Zúñiga con quien Huenún dialoga en Reducciones. Tras su destrucción en 1602, es refundada nuevamente en 1792 durante el mandato de Ambrosio O'Higgins, padre de quien sería más tarde el fundador de la República de Chile, Bernardo O’Higgins.

156 
identificando a los agentes que las han infringido y a sus víctimas, pero igualmente evidenciando los discursos que las revelan, las encubren, las naturalizan desde diversas orillas etnoculturales, se vuelven dramáticamente dañinas para los tránsitos dialógicos entre culturas. Chauracahuín deviene, pues, nombre del ejercicio poético de historizar radicalmente los lugares de la memoria.

El cronotopos Chauracahuín se eleva a la condición de sinécdoque geográfica del mestizaje latinoamericano y, en rigor, de cualquier mestizaje acontecido como resultado de la violencia colonial institucionalizada y sostenida en el tiempo en un territorio determinado. Entrar a Chauracahuín no es simplemente revisitar y dar cuenta de un lugar o de un paisaje realmente existente, Osorno en este caso; es, por sobre todo, asomarse a la tragedia de la historia y hacer de ella y con ella una poesía que atestigüe la trashumancia, las traducciones y mutaciones identitarias de quienes hasta ahora han sido los perdedores de la modernidad latinoamericana. Huenún hace de las "reducciones" históricas puntos de encuentro y confluencias de memorias y lenguajes varios que en su conjunto y siempre en permanente reconfiguración constituyen e instituyen los lugares poéticos de la vida que son, al mismo tiempo y por complemento, los de la muerte y de la memoria evocadora; son los lugares de los sueños visionarios y de la mirada cotidiana de lo que está ahí, lugares hechos por las palabras con las que se sostiene el interminable nütram (conversación mapuche) de la poesía y de la vida: es la champurria de los condenados de la tierra.

\section{PERFORMATIVIDAD DE LA POESÍA}

La ficción poética, llevada a la tarea de tener que lidiar con la realidad "fuerte" de las materialidades históricas efectivamente acontecidas, pareciera ser una palabra "débil", que se refugia en el tranquilo remanso de las metáforas y que no hace sino evocar sombras ("cantos de sombra", diríamos en palabras de Léopold Sédar Senghor, poeta senegalés que cantó su África en un francés expropiado a los amos blancos) $)^{12}$. La poesía entonces, si se la mide con la vara de la acción efectivamente transformadora de la realidad, parece "una historia de locos", como bien dice Antonio Cisneros; pero, como el propio poeta peruano acota, es con la poesía que se formulan las "inmensas preguntas celestes"13. Así, al evocar esas sombras-voces de ayer y hoy, la poesía de Huenún recupera huellas de lo vivido, denuncia acciones injustas que han quedado silenciadas en los recodos de la historia, construye discursivamente propuestas de sujetos que nos interpelan a que nos sacudamos de las asfixiantes categorizaciones con que la ciencia blanca decimonónica (léase historia, antropología, fisiología humana incluso) clasificaba y calificaba las sociedades e individuos según presuntos grados de civilización, escenario en el que los sujetos indígenas llevaban siempre la peor parte. Enfrentada a las aberraciones de la arrogante ciencia blanca (y

\footnotetext{
${ }^{12} \mathrm{Cf}$. Cantos de sombra de Sédar Senghor.

${ }^{13}$ Cf. Poesía, una historia de locos (1962-1980) y Las inmensas preguntas celestes de Antonio Cisneros.
} 
no solo la del siglo XIX), la "débil" palabra poética se hace entonces éticamente "fuerte" y políticamente insubordinada.

Es, al respecto, significativa la sección "Cuatro cantos funerarios" de Reducciones. Paradójicamente los "cuatro cantos" no son cantos sino cuatro informes que "cantan"/denotan la incapacidad de la cultura blanca europea de tratar con su otredad. La sección se inaugura con un epígrafe tomado de una canción aché-guayakí (ya citada) y fragmentos de tres informes "técnicos" cada uno referido a personas indígenas reales de quienes, además, se acompaña retratos fotográficos: Damiana, escrito por Robert Lehmann-Nitsche en1908; Catriel, escrito por Francisco Pascasio Moreno en 1875 (ya citado); Maish Kenzis, escrito por Herman Ten Kate en 1906. A estos se suma un cuarto "canto" cuyo título es una declaración de Hans Virchow, de 1867, "He disecado muchos cadáveres y nunca he encontrado el alma" (73), seguida de la fotografía de época, una calavera y un texto final de Huenún "Cisne de mí". "Cantos" que hablan de muertes indígenas, pero también de la muerte moral y cultural de la sociedad blanca que construye un conocimiento que deshumaniza radicalmente al otro.

Nos hallamos ante una poesía que viaja a contracorriente por el río turbio de la historia hurgando en los residuos y sedimentos que yacen invisibilizados en su lecho. Río este que en Reducciones se corporiza en el Rahue, que divide Osorno en dos mitades étnicas socialmente desiguales y que fluye, aguas abajo, por la vegas de Quilacahuín. Río Rahue que Huenún, mediante el poder evocador y constructor de mundos que detenta la palabra poética, pondrá patas arriba para que se vuelvan a oír los gritos de los antiguos boteros: los Manquilef, los Rauque, los Huenteo, los Huisca, los Huenún... y para que los cantos de las bandurrias contribuyan a la poesía trayendo de vuelta la murmurante sombra benefactora de los ancestros del poeta cuando estos, envueltos por las nubes de la vida y la muerte, subían y bajaban los repechos de su tiempo. La fuerza de una poesía como la de Reducciones no pasa por la defensa de una determinada doctrina que modele o prescriba una cierta acción política de "intervención rápida" (metáfora militar que el lector sabrá excusar) cuyos efectos podrían ser inmediatos y mensurables; su eficacia, si se puede así decir, viene del hecho de ser un discurso que trabaja a favor del fortalecimiento de subjetividades arrojadas a la intemperie de un mestizaje que se vive a menudo como experiencia de deterioro o pérdida de una identidad pretérita de alcances colectivos.

$\mathrm{Y}$ tal fortalecimiento del sí mismo ${ }^{14} \multimap$ o arropamiento de la subjetividad, sería mejor decir-, acontece en la medida en que la poesía dota a los sujetos de una memoria de liberación que transmuta la tragedia en ceremonia de amor y vida al otorgar carta de ciudadanía a todos los cantos: hablamos de los cantos fúnebres; de aquellos que transmiten la serena contemplación de una muchacha que baila y se pierde tras el polvo que levantan los pies de los danzantes; de los que

\footnotetext{
${ }^{14}$ Tomo la expresión de Harold Bloom: "Se lee para fortalecer el sí mismo (el self) y averiguar cuáles son sus intereses auténticos". Cómo leer y por qué. Versión digital, sin paginar.
} 
recrean/rememoran los lugares sagrados que la naturaleza cobija en los bosques, el mar, los ríos; de los que denuncian o atestiguan la colonización de la mente y las palabras; de los que relatan experiencias autobiográficas del poeta y que son cruciales para que su palabra cobre su cuota de realidad cotidiana tanto como su cuota de visión metafísica: el pewma (sueño visionario) que pone al poeta vidente indígena mestizo en concomitancia con el poeta vidente moderno — Rimbaud principalmente - a la hora de leer los signos numinosos de las cosas; en fin, hablamos de los cantos que interpelan a los agentes que son constructores profesionales de narrativas históricas (al historiador Gabriel Salazar, por ejemplo).

seguiremos escribiendo sobre abuelas, Salazar,

la mía por ejemplo trabajó 70 años

en las fraguas alemanas

y leyó los Himnos a la Noche

en los kuchen de frambuesas y de nata

y en la hiriente soda cáustica

que blanqueaba los retretes hacendales.

fue manceba de un navarro, carnicero y vagabundo

y parló en che sungun sus lentas y augurales pesadillas; tuvo un hijo y fueron mil

las descendencias de sus manos

en las rocas, en las aguas cerriles

de una torva vecindad.

qué me dices, Salazar, cómo te explico

sus albricias,

la carne que ha comido, el bacín debajo de su cama.

las abuelas, Salazar, son cosa seria [...] (163).

(de "Testimonio")

Escribir sobre abuelas (y otorgarles voz en la escritura) constituye uno de los sellos de agua de Reducciones. Escribir se vuelve desentierro arqueológico de aquellas memorias que han quedado en la trastienda de una historia de la que los historiadores suelen con frecuencia ignorar los pliegues y repliegues de las pequeñas y grandes tragedias cotidianas anónimas. Reducciones en este punto admite ser leído como un esfuerzo de construcción de una narrativa mapuche huilliche-mestiza que hace justicia a los ancestros literarios de Huenún, a las genealogías de su lengua poética, mediante la conformación de una trama textual de varia lección: el texto documental, cronístico; el relato autobiográfico y testimonial; el poema en verso libre que asume con frecuencia un tono versicular; el epigrama que evoca una escena lírica particular que recuerda el hai ku japonés y que retrata una acotada interacción entre el yo hablante y la naturaleza, como en este brevísimo poema de la sección "Envíos": "Un tigre he dibujado/ en el arroyo/ para que el agua libre/ se defienda" (90); fotografias de archivos familiares e históricos; fragmentos de cantos indígenas tradicionales; textos "científicos" de antropólogos, fisiólogos y anatomistas europeos 
decimonónicos; reescrituras de crónicas hispánicas coloniales que conservan su español arcaico así como textos que evocan la lengua de Castilla hablada en clave de un che sungun triturado por la maquinaria de la colonización; todo ello, y más, conforma una polifonía que permite un constante y productivo desplazamiento por los territorios de la memoria y la imaginación insubordinadas.

Si hay algo determinante en Reducciones es su poderoso realismo poético que se expresa precisamente en la diversidad textual que viene a evidenciar la diversidad instituyente del sujeto lírico, al que, por otra parte, no hay que ver como un sujeto, un yo particular, sino como una instancia plural de dialogicidad y romanceo. Y no podría ser de otro modo si el propósito es, como en efecto lo es, atestiguar, documentar con la poesía y en ella, la construcción de un mundo poético que no pretende sino ser la expresión de identidades culturales (y políticas) entrecruzadas, fragmentadas, descentradas, que se han venido haciendo con los restos de ya fenecidos modos de ser y vivir rurales o pueblerinos, pero que ahora, en los inicios del siglo XXI, cobran sentido restituyente de una memoria cultural que bien podríamos calificar de insurgente. Restos que constituyen, a su vez, la base material de una imaginación poética que trabaja contra aquella forma de sedentarismo ideológico que favorece la deshistorización de la realidad sociocultural. Reducciones, en este sentido, se nos propone como una épica de la acumulación de fuerzas simbólicas de parte de sujetos subalternos indígenas o indígena-mestizos, de manera que el proceso de "reducción" ontológica se revierta en beneficio de un fortalecimiento del sí mismo (personal y colectivo) al punto de transmutarse en sujetos emancipados del oprobio colonizador y protagonistas entonces de una historia más justa, más democrática, más reconocedora de los olvidados. La poesía de Huenún $-\mathrm{y}$ no solo la que hallamos en Reducciones - es una escritura éticamente comprometida con los que han sufrido y sufren la historia, haciendo de lo cultural, lo político y lo estético esferas de acción unificadas por la performatividad historizadora de esta poesía.

"Seguiremos escribiendo sobre abuelas", nos notifica el poeta. Y cómo no, si de lo que se trata es justamente escribir acerca de abuelas y abuelos, porque de ellos, del recuerdo de su palabra, emana la fuerza iluminadora de la poesía, y de la poesía la potencia sanadora de una historia de oprobio y daño. De la remembranza de las cotidianidades de los ancestros, oscurecidas tanto tiempo por la niebla espesa de las injusticias mañosamente olvidadas, viene la raíz vital de una palabra poética cuyo sentido último es construir puentes de memoria que visibilicen a tantos que han sido arrojados a los territorios baldíos y desechables del "progreso" de la nación. Cotidianidades que por la poesía justamente dejan de ser olvido y se vuelven presencia constructora de un tiempo venidero en que la muerte no tendrá otro señorío que el que le otorga el orden natural de las cosas. Visión inagotable de una tierra reducida a población callampa en las ciudades de la república, a pequeñas parcelas pobres en los faldeos cordilleranos de San Juan de la Costa, a plantaciones de pino y eucalipto en tierras que cobijaron antiguos bosques en los que floreció el copihue aferrado con todos sus zarcillos al oloroso melí, reducida a poesía de los vencidos. 
Porque Reducciones es también, como ya se ha sugerido, la crónica de una derrota que no ha terminado; al contrario, en muchos aspectos la modernidad consumista de hoy la ha profundizado dramáticamente. Los degradados mundos indígenas, convertidos en tugurios de exotismo mercantilizado, constituyen parte sustantiva de las reducciones provocadas por un orden neoliberal extremo que convierte las identidades indígenas en mercancías. Muchos indígenas $-\mathrm{y}$ que proclaman serlo- hacen o han hecho de su condición subalterna un "negocio" que puede llegar a ser bastante rentable incluso:

\author{
Vi no más al indígena \\ buscar la fama / el orgullo buscar \\ el bajo y velludo vientre de la gringa \\ al poeta bilingüe persiguiendo a su exegeta \\ a la cabra brichera \\ filmada por el ojo de Cíclope \\ de un hispano-danés-británico-francófono \\ Las lenguas se tocan hermanitos \\ y se revuelve sin cesar \\ el gallinero altiplánico \\ el gallinero amazónico \\ la sangrienta pirámide mesoamericana \\ EL SUCIO CORRAL DE LOS PROMAUCAES ${ }^{15}$ \\ EN EL LONGO VALLE DEL MAPOCHO \\ (de "Carta a los suelos", 159)
}

La poesía de Huenún es un modo de tratar a/con identidades dañadas, indígenas y blancas, de manera que la escritura literaria contribuya a resarcir esos daños con la palabra poética y crítica, evocadora de ternuras y tragedias. Esto implica atribuirle a la poesía, a la literatura, una función político-terapéutica que desborda, creemos, los límites del campo estético tal como este se le suele entender habitualmente: un quehacer que se autocontiene dentro de sus propios límites y se legitima con reglas que le serían propias y excluyentes. Estamos, pues, ante una poesía moderna que cuestiona radicalmente aquellos modos aberrantes de ser moderno como lo es la dominación colonial y sus reificaciones que colisionan con la memoria historizada y emancipatoria. La ciudad moderna sea acaso el lugar privilegiado del olvido, por el aturdimiento que provoca su tráfago incesante que ignora los tiempos de la naturaleza, pero sobre todo porque sería el no lugar de identidades flotantes y desarraigadas que, en tanto tales, se vuelven una especie de no identidades sometidas a la persistente exigencia de dejar de ser. Ser mapuche o mapuche huilliche en la ciudad, quiero decir, retener la memoria ancestral y existir

\footnotetext{
${ }^{15}$ Promaucae: Enemigo salvaje, en quechua. Nombre que daban los incas a etnias que habitaron el actual territorio central de Chile, entre el los ríos Maipo y Maule. Recordemos que los incas avanzaron más o menos hasta el río Maule y, en su expansión, fueron precisamente frenados por los mapuches.
} 
conforme a ella, es una batalla épica contra la niebla de una historia que pareciera, paradójicamente, no tener historia. El trabajo de la poesía consiste en despejar esta niebla, a sabiendas de que es una batalla de desenlace incierto y, en todo caso, siempre será un despeje parcial: con la poesía haremos islas de memoria, parches para identidades mestizas en curso, en trayectoria; proveeremos imágenes que nos devuelven a retazos a la delicada mancomunión con los elementos. No deja, pues, la poesía de ser testimonio de una historia deseada pero condenada asimismo a su irrealización.

La ciudad viene hasta ti con sus ácidas cadenas y esas grúas que levantan los cimientos de la historia. Son nublados palacetes donde anidan pardos búhos y la opaca lluvia andina de la tenue Cruz del Sur.

Las ciudades son ahora el final de tu memoria, la escritura humedecida de tus sueños siempre nómades.

Es por ello que no olvidas una plaza, una explanada donde el pueblo erige a tumbos una gris catedral.

Tras murallas ves un barco de antimonio sobre el aire, y carruajes de caballos emplumados en los muelles, traficantes de palomas, pavorreales, guacamayos, mil esclavos que te venden sus cabezas y sus sexos.

¿Y qué puedes dar a cambio por la urbe que te ofrecen?

Ni semillas ya, ni lenguas, ni tratados, ni armamento: tu destino entre nosotros es falaz como la arena, un gobierno de cuchillos en el agua nocturnal.

("Fundaciones II", 50)

No sería ocioso recordar que la ocupación de territorios indígenas en el sur chileno se hizo a partir de la fundación de ciudades enclavadas en puntos estratégicos de manera que aseguraran primero la discontinuidad del territorio indígena y luego la ocupación rural —que se materializó sobre todo con la llamada colonización alemana en el siglo XIX - , dando paso a la emergencia de una agricultura extensiva industrial en manos de una elite de terratenientes de ancestros europeos no españoles. Las ciudades a su turno resultaron ser puntos de atracción de la migración campo-ciudad de muchos indígenas, así como espacios de degradación de la antigua memoria identitaria rural. Pero es también en las ciudades donde el mestizaje, la heterogeneidad cultural, las capas de memoria, las migrancias identitarias, el acceso a la modernidad occidental en sus distintas facetas, han devenido condiciones de posibilidad para la emergencia de la poesía de las memorias culturales puesta - la poesía - a la tarea de construir una semiósfera democrática que contribuya a la descolonización efectiva del devenir histórico. 
"Un gobierno de cuchillos" y un "destino falaz" dominan la escena (del) presente. Pero ese destino que no será, no tiene por qué ser, siempre falaz. Y los cuchillos tendrán que servir para rasgar la niebla del futuro:

\author{
Ya vendrán tiempos mejores, \\ hermanito, \\ para izar los sangrados estandartes \\ en llanuras y montañas \\ liberadas por los pewma \\ de la Banca y la Escritura. \\ Por ahora, \\ ya sin broncas ni leyendas \\ /ni tardíos editores/ \\ vuelvo a casa. \\ Traduciendo mis poemas al spanglish, \\ /al patois/ \\ y al sudado creole de las Antillas, \\ vivo holgado de mis rentas \\ /mis derechos/ \\ MI LEGÍTIMO KIMUN/MI RAKIZUAM. ${ }^{16}$
}

(de "En la ruka de David", 162)

Nótese que el poeta escribe "sangrados" y no "desangrados". Nótese el valor liberador de los pewma mapuche. Nótese el reclamo por un nuevo orden que no sea el de la Banca y la Escritura; nuevo orden que no pase por encima de los cuerpos, las aguas, el cielo, el viento que mueve el árbol de la poesía. Reducciones "es un libro en crecimiento arbóreo", sentencia Huenún. Habrá entonces que plantar este árbol en lo alto de las colinas de Quilacahuín para que desde sus ramajes en movimiento podamos otear el amplio horizonte de las cosas visibles y muy principalmente el de las invisibles. No para arrasar con la iglesia o el colegio o el hospital básico de la Misión de Quilacahuín, como en su momento, y para inmensa desgracia de la humanidad, sí lo hicieron los españoles conquistadores en México, en Perú; como los estados nacionales, a su turno, igualmente hicieron, y aun peor (recordemos el genocidio de la así llamada "Conquista del Desierto" en Argentina y su homóloga la "Pacificación de la Araucanía" en Chile, o el exterminio de los indígenas de la Patagonia chilena a inicios del siglo XX). Para que el árbol de la memoria y el conocimiento florezca para todos en todas las estaciones de todos los años. Y que no quede solo la imagen de un canelo polvoriento y moribundo que el poeta conociera en su infancia y que resultó ser uno que plantara Gabriela Mistral en la plaza de Osorno

\footnotetext{
16 "Kimún" alude a la constelación semántica conocimiento, saber, sabiduría, en tanto que "Rakizuam" alude a pensamiento, conciencia. El poema dialoga con David Añiñir, poeta mapuche contemporáneo, creador de la noción de "mapurbe" para referirse a la heterogénea identidad mapuche citadina de sujetos indígenas que viven en espacios metropolitanos degradados, subalternos en cualquier caso.
} 
en 1938 en un gesto de homenaje a la gente morena que habitaba y aun habita un Chauracahuín de miserias ${ }^{17}$.

Para que la memoria iluminada de María Matilde Huenún Huenún, niñamujer-madre-abuela, hoy ya fallecida, quede fulgurando en los bellos amaneceres de Quilacahuín.

\author{
Universidad Austral de Chile* \\ Instituto de Lingüistica y Literatura \\ Casilla 567, Valdivia (Chile) \\ changuitad@gmail.com
}

\title{
OBRAS CITADAS
}

Anónimo. Poema de Mío Cid. Buenos Aires, edic. digital. www.infotematica.com.ar Araya, Pedro (ed.). Metáforas de Chile. Santiago: Corporación Altamar/ LOM, 1999. Bengoa, José. Historia del pueblo mapuche. Santiago: Ediciones Sur, 1985.

Bloom, Harold. Cómo leer y por qué. Bogotá: Norma, 2000.

Cisneros, Antonio. Las inmensas preguntas celestes. Lima: Jaime Campodónico, 1992. Poesía, una historia de locos (1962-1980). Madrid: Hiperion, 1990.

Huenún Villa, Jaime. Reducciones. Santiago: LOM, 2012.

Rojas, Rodrigo. La lengua escorada. La traducción como estrategia de resistencia en cuatro poetas mapuches. Santiago: Pehuén, 2009.

Sédar Senghor, Léopold. Cantos de sombra. Madrid: Visor, 1980 (1945, $1^{\text {a }}$ ed.).

17 "Una noche de mi niñez, a fines de la década del 70, supe por boca de mi abuela que un árbol ya entonces polvoriento y moribundo, desflorado para siempre en la raíz y el agua, era el canelo que Lucila Godoy había plantado en la señorial Plaza de Armas de la ciudad de Osorno" (23). Descontando el epígrafe inicial, este es el comienzo de Reducciones. El canelo es el árbol sagrado del pueblo mapuche. 